\title{
Civic advocacy for public service media? The case of Switzerland and its current rise in media policy activism
}

\author{
Schweizer, Corinne
}

\begin{abstract}
Civic advocacy for public service media (PSM) is rather rare. Switzerland, however, where civic associations play a vital role in politics and economy and media policy activism is currently on the rise, offers ideal conditions for such advocacy. Combining document analysis and expert interviews with leading activists, this article investigates the aims, strategies, and networks of seven associations dedicated to media policy activism. It also examines the connection between No Billag, a 2018 national referendum on abolishing the public broadcasting license fee, and the formation of new associations. Findings show that these associations are gatherings of media professionals and that PSM is not their main concern.
\end{abstract}

DOI: https://doi.org/10.1386/iscc_00016_1

Posted at the Zurich Open Repository and Archive, University of Zurich

ZORA URL: https://doi.org/10.5167/uzh-187957

Journal Article

Accepted Version

Originally published at:

Schweizer, Corinne (2020). Civic advocacy for public service media? The case of Switzerland and its current rise in media policy activism. Interactions : Studies in Communication Culture, 11(2):159-176.

DOI: https://doi.org/10.1386/iscc_00016_1 


\title{
Civic advocacy for public service media? The case of Switzerland and its current rise in media policy activism
}

\author{
Corinne Schweizer https://orcid.org/0000-0002-7591-7556
}

\begin{abstract}
Civic advocacy for public service media (PSM) is rather rare. Switzerland, however, where civic associations play a vital role in politics and economy and media policy activism is currently on the rise, offers ideal conditions for such advocacy. Combining document analysis and expert interviews with leading activists, this article investigates the aims, strategies, and networks of seven associations dedicated to media policy activism. It also examines the connection between No Billag, a 2018 national referendum on abolishing the public broadcasting license fee, and the formation of new associations. Findings show that these associations are gatherings of media professionals and that PSM is not their main concern.
\end{abstract}

\section{Keywords}

media policy, activism, associations, Switzerland, No Billag, public service media (PSM), case study

\section{Contact}

Dr. Corinne Schweizer, IKMZ - Institut für Kommunikationswissenschaft und Medienforschung, Universität Zürich, Andreasstrasse 15, AND 3.86, CH-8050 Zürich, Switzerland, 


\title{
Civic advocacy for public service media? The case of Switzerland and its current rise in media policy activism
}

\author{
Corinne Schweizer https://orcid.org/0000-0002-7591-7556
}

\section{Introduction}

Civic advocacy for public service media (PSM) is rather rare. In Switzerland, however, where civic associations play a vital role in the political process and the economic system, conditions seem ideal for a social movement in support of PSM. Moreover, indeed, similarly to the Nederlandse Publieke Omroep (NPO), the Swiss Broadcasting Corporation (SRG) is based on a network of membership organizations that are open for everyone living in Switzerland to join (see SRG SSR n.d.). Outside the PSM system, there are further associations advocating for the public interest in the media industry. Their number is rising as several new associations - e.g. Media Diversity, Media for All or Strong Media - have emerged in the last six years, complementing existing associations such as the Workers Radio Association and Quality in Journalism.

The rise of media policy activism as a form of advocacy for the public interest in the Swiss media industry is the focus of this study. Research findings from other contexts allow formulating assumptions about the phenomenon: first, media policy activism normally consists of an alliance between the civil society and public interest groups, sometimes also including partners from the state and the commercial sector (e.g. Fenton 2018; Hintz 2018). Second, building a sustainable organization and mobilizing the public is a major challenge for media policy activists due to the lack of financial resources (Regan Shade 2011) and because of the 'sheer breadth, interrelatedness and complexity' (Lentz 2011: 323) of media policy. And third, media policy activism can benefit from broader normative or ideological trends, but it often requires a specific 'policy window' to gain momentum: a 'temporary opening [...] in which established social orders become receptive to change and new actors can enter the field and advance their agendas' (Hintz 2018: 321, see also Kingdon 1984).

The current rise of media policy activism in Switzerland does indeed coincide with a 'policy window'. In the last six years, Swiss citizens have voted twice on national referenda about the funding of PSM. While direct-democratic Switzerland holds national referenda several times a year since the nineteenth century, there have been hardly any referenda on media policy before 2015.1 In the last six years, however, the Swiss voted on a referendum against the introduction of a household levy instead of the licence fee (2015) and on a referendum called No Billag on abolishing public funding for PSM and for the entire media industry (2018). Both referenda were rejected by the voters after intense debate. No Billag, because of its potentially far-reaching consequences, triggered 'several months of emotional campaigning by political groups and a broad range of civil society groups' (Geiser 2018: n.pag.) and intense media coverage (fög 2018).

The goal of this study was to understand why media policy activism is on the rise in Switzerland and what role PSM play in the agenda of associations dedicated to it. The study also sought to find out whether the rise was triggered by the 'policy window' that was opened by the No Billag referendum. To answer these questions, the study used a mixed-methods approach - document analysis and 
interviews with leading activists - to investigate the aims, strategies and networks of seven associations. Starting with the state of research on media policy activism, the article then focuses on Switzerland and the research design of this case study. In the main section, it describes the three themes found in the empirical analysis - 'It was not so much No Billag, but', 'Ideally, we would do much more' and 'It is a small biotope' - before discussing their implications for the advocacy for PSM in the concluding section.

\section{Media policy activism and the media reform movement}

Freedman defines media policy activism as 'a form of advocacy that is focused on achieving structural transformations within the media landscape' (2019: 628). Media policy activists are 'focused on the legal and regulatory conditions of media production' and they 'intervene in processes, debates and institutions that regulate, enable or obstruct media practices and communications infrastructures' (Hintz 2018: 319). In academic research, however, the concept of media policy activism often overlaps with related concepts such as media reform, social movements, alternative media or media literacy, which is discussed next.

\section{The media reform movement and its main activities}

Many authors summarize various forms of civic advocacy for the public interest in the media sector citizen's initiatives, policy interventions, etc. - under the umbrella term 'media reform movement' (see e.g. Napoli 2007: 8-9; Regan Shade 2011: 147). In general, social movements are 'key forces of social change' (Johnston 2014: 1) that typically stand outside established political and institutional structures. Social movements are networks of various individual organizations that share ideas, ideologies, interests and identities (Johnston 2014: 7-20). As most contemporary social movements aim at influencing laws, policies and government officials, they are both social and political movements (Johnston 2014: 49). Whether they are also cultural movements is more difficult to establish (Johnston 2014: 72-93).2

Media reform includes activities that aim at 'knowing', 'being' or 'changing' the media (Freedman and Obar 2016: 6-12). Accordingly, a first media reform activity is to know the media and to formulate a critique of their content or structures. Several authors (Freedman 2019; Lentz 2016; Ugland 2019) describe media (policy) literacy as a prerequisite for any attempt at media reform and call for its promotion in schools and universities. A second media reform activity is to establish alternative or community media. The fight of radio pirates against the monopolies in the broadcasting era of the twentieth century is well documented. Nowadays, despite many of them being officially licensed, these media still stand for social change, democracy and freedom of expression (Rennie 2011). A third media reform activity is, finally, to try to change the media through media policy activism.

Oftentimes, media policy activists apply an 'inside strategy' of engaging cooperatively and constructively in the political process by submitting statements and engaging in conversations with powerholders (Hintz 2018: 322). To a lesser extent, media policy activists apply an 'outside strategy' that is more characteristic for social movements in other fields: with public protests, rallies or demonstrations, they exert public pressure, express dissatisfaction and demand change (Hintz 2018: 323). Furthermore, media policy activists might apply a 'beyond strategy' (Milan and Hintz 2011: n. pag.; Hintz 2018: 324) that resembles Freedman and Obar's second media policy activity: by creating alternative communication infrastructures, activists can change the media sector by bypassing the political process altogether. 
Based on Regan Shade (2011: 150, 152), one could also add a fourth element to Freedman and Obars' formula of knowing, being and changing: making the media more equitable. Despite their aim for democratizing the media, media reform movements and media policy activism have often missed to adequately address the structural impact of class, race, gender, sexuality or disability. A similar lack of intersectional thinking marks academic research. Some good examples are, however, Moran and Bui's (2019) study on race, ethnicity and telecommunication policy, Gallagher's (2011) overview on gender and communication policy and Ellis and Goggin's (2018) discussion of disability and media activism.

Actors, topics and challenges of media policy activism

Research connecting media with activism often focuses on the ways movements use media and digital technology. Such studies either ask how movements can attract favourable media coverage (e.g. Feigenbaum 2018) or how they connect their online and offline activities (e.g. Kavada 2018; Dencik and Wilkin 2018). While the latter is relevant for media policy activism as well, the first question is particularly relevant. As the target of their critique, media organizations, whose business is at stake, might fail to report neutrally and objectively about media policy activists. Media are themselves involved in the 'politics of media policy' (see Freedman 2008); it is therefore reasonable to assume that activists in this field struggle even more to receive media support than those in other fields.

Another 'major challenge' (Regan Shade 2011: 159) for media policy activism is building a sustainable organization and mobilizing the public due to the lack of financial resources. While this is also true for other social movements, media policy activism seems to suffer from the 'sheer breadth, interrelatedness, and complexity' (Lentz 2011: 323) of its cause. Accordingly, citizen involvement in media policy activism might be rather rare. Media policy activism can, however, benefit from broader normative or ideological trends and it gains momentum when a specific 'policy window' opens (see Hintz 2018). The global debate on 'Fake News' and the No Billag referendum in Switzerland are good examples for potential 'policy windows'.

Media policy activism normally consists of an alliance between civil society and public interest groups, sometimes including partners from the state and the commercial sectors (Fenton 2018; Hintz 2018). While all these groups generally advocate for the public interest in the media sector (Regan Shade 2011: 147), they differ quite considerably in terms of their particular objectives, motivations, guiding principles, their framing of issues, their policy priorities, their techniques and their strategic activities (Freedman and Obar 2016: 5; Napoli 2007: 12). Accordingly, media policy activism or social movements in general are by no means free of tensions. In a case study about the net neutrality movement in the United States, Löblich (2016) found that civil society organizations ended up on opposing sides of the debate. Borgman-Arboleda (2011) and Karaganis (2011) discuss how to avoid tensions when facilitating collaborations between scholars and activist in media and communication policy. 3

While most of the literature in English speaking academia focuses on media policy activism in Europe and the United States, we also find case studies about such movements in Africa (e.g. Okon 2017) or Latin America (e.g. Soledad Segura and Waisbord 2016 ). Some researchers investigate activism in closely related fields such as net neutrality (e.g. Dunham 2016), intellectual property or copyrights (e.g. Boateng 2011; Collins 2018) or more generally digital activism (e.g. Milan 2013). Some scholars also focus on the role of academia in media policy activism (see e.g. Skinner et al. 2015). In Switzerland, for example, media and communication scholars are regularly involved in policy-making but fall short in advocating for the public interest as they tend to align too much with political and media elites (Puppis and Künzler 2016).

According to Aslama Horowitz and Nieminen (2017), PSM has never been at the centre of media policy activism or related academic theorization and empirical analysis. An exception is Horz' (20186) study on 'public service media challengers'. Based on an in-depth examination of four audience initiatives in 
Germany, Italy, Spain and Switzerland - she spoke with Media Critique that has dissolved in 2017 (see next section) - Horz differentiates between three main goals of PSM challengers: Represent general audience interests, safeguard the future of PSM, or boycott PSM institutions and financing schemes. The study also found that it is often 'well-informed groups' (Horz 20168: 239), including scholars and journalists that advocate for PSM.

\section{The case of media policy activism in Switzerland}

Forty-two per cent of the Swiss citizens are members of at least one association (Galliker 2018: 6); overall, there are probably around 100,000 associations in Switzerland (Schumacher 2017: 4). Civil society organizations generally play an important role in politics: '[d] ue to liberal government policies and a strong tradition of citizen self-management [...] they are involved in nearly every political decision' (Helmig et al. 2011: 25). While there is academic literature available on civic activism in Switzerland, this is the first comprehensive study on media policy activism and associations dedicated to it so far.

\section{Civic advocacy and the political function of associations}

Compared to other developed countries, Switzerland has a sizeable civil society sector, accounting for 6.9 per cent of the country's working population (Helmig et al. 2011: 11-12). Approximately 14 per cent of this sector's activities are 'expressive' in nature, in contrast to 83 per cent dedicated to the provision of specific services (Helmig et al. 2011: 15). Expressive activities include social movements, advocacy or network and community building in the name of cultural, religious, professional or policy values and interests (Helmig et al. 2011: 5-6). Most expressive activities fall into the subfields of sports, recreation or culture; advocacy, in comparison, is a niche activity. Expressive activities rely heavily on volunteer work (Helmig et al. 2011: 15): while advocacy groups in Switzerland receive some financial support from the government (11 per cent) and from philanthropy ( 6 per cent), their most important stream of income (83 per cent) are their membership fees (Helmig et al. 2011: 16).

In Switzerland, civic advocacy normally takes place inside of associations. Due to simple legal requirements (e.g. Strub 2018 ), associations can emerge and dissolve very quickly.4 Accordingly, they serve as a 'seismograph' for citizens' needs and for the Zeitgeist (Galliker 2018: 6). When they first emerged in the eighteenth century, associations were tight social circles ('societies') interested in culture and science. In the nineteenth century - the golden age of associations - Switzerland had one association per 100 citizens (Galliker 2018: 29), covering increasingly specialized needs (Jost 1992: 476). In the 1960s and 1970s, associations incorporated ideas of new social movements that were fighting for plurality, social justice or gender equality (Galliker 2018: 43). In recent years, there is a paradoxical situation: while membership numbers decrease, there is a renewed interest in civic activism and a 'third sector' outside the binary of state and market (Schumacher 2017: 46-47).5

Very few associations - aside from political parties and unions - declare themselves to be 'political'. This conceals how strong the politization of the Swiss association system is in general (Jost 1992: 48182). Associations helped building modern Switzerland and are used to taking over tasks that are elsewhere carried out by the government or the administration. Accordingly, Swiss associations function like public corporations. Public service broadcaster SRG is, as already mentioned, a private association with a public mandate and therefore a good example for this. Furthermore, it would hardly be possible to have a political career in Switzerland without a membership in at least one association 
(Jost 1992: 482). Not only do associations offer a training ground for prospective politicians by allowing them to practice public speaking, they also create networks beyond the local level.

\section{Associations dedicated to media policy activism in Switzerland}

The oldest association in the field of media policy activism in Switzerland is the Workers Radio Association (Arbus). Founded in 1930, it still promotes critical media usage and media reform. One year after Arbus, the Swiss Broadcasting Corporation (SRG) was founded, an association whose main task is to provide public service broadcasting (Art. 1-2 SRG Statutes).6 Its four membership organizations - SRG.D, RTSR, Corsi and SRG.R - cover the four linguistic regions of Switzerland (Art. 3 SRG Statues). Some of their 25,000 members are elected into regional councils or commissions. Most of them are, however, senior citizens that might attend annual meetings, studio visits or seminars on various topics. Several authors (see e.g. Baldi 20078 ; Puppis and Künzler 2011; Tuchschmid 2015) describe the SRG's membership organizations as 'toothless' when it comes to media policy activism.

In 1999, journalists and media scholars founded Quality in Journalism (QuaJou), an association dedicated to promoting and safeguarding quality in media content and reporting. A similar association, Media Critique, was founded in 1997 but dissolved in 2017. In 2015, artists, journalists and TV producers founded Media for All, an association promoting PSM, plurality and democracy. In 2017, journalists, scholars and small-media owners founded Strong Media ('Media Forti'), an association dedicated to future-proof journalism. Media Diversity (2017) and Media Future Basel (2019) were founded by locals of Winterthur and Basel to safeguard diversity and factual reporting. In 2017, also Media with a Future (VMZ) was founded by small media organizations. Their association advocates for diversity and competition in journalism. Several members of VMZ - e.g. Republik, Tsüri.ch or WOZ are themselves associations depending at least partly on membership fees.

Other associations dedicated to media policy activism can be allocated to Jost's categorization (1992: 477-81): like in other sectors, there are trade and industry associations (e.g. the Swiss Media Association), professional organizations (e.g. imPressum, Media Women, Young Journalists) and labour organizations and unions (e.g. Syndicom, Swiss Syndicate for Media Workers, UNIKOM). Finally, there is media policy activism led by political parties: In 2008, politicians from the Swiss People's Party (SVP) and the Liberal-Democratic Party (FDP) formed Action for Media Freedom to promote the liberalization of the media market. In 2018, the Green Party established a media policy network to work towards more democratic media, which has not turned into an association yet.

\section{Research design: Document analysis and expert interviews with leading activists}

Case studies are 'intensive investigations' (Broughton Micova 2019: 73). They can either serve as a testing-ground for existing theories or they provide new insights for further research (Broughton Micova 2019: 74). This article sought to understand why media policy activism is rising in Switzerland, how activist groups are organized and what role PSM play in their agenda. Furthermore, it sought to clarify the connection between No Billag, and the formation of new associations dedicated to media policy activism. Although the findings of case studies cannot be generalized (Broughton Micova 2019: 74; see also George 2005; Yin 2009), the article provides an insight into the complex phenomenon of media reform movements and media policy activism that is valuable for those who are studying these subjects in another context.

A case is normally selected because it is critical, typical or unique (Broughton Micova 2019: 77). While media policy activism might be common (typical) in several countries, the social, cultural, economic and political situation in Switzerland provides a unique context. Furthermore, the selection of the right 
kind of associations is critical. First, they need to advocate for public service or public interest media. Second, they need to be part of the civil society, either by including civic members, or by representing the public instead of a private interest, or by providing an alternative to 'big business' in the media sector. Based on these considerations, seven associations were selected (see Table 1): Arbus, Media Diversity, Media for All, Media with a Future (VMZ), Media Women, Strong Media and Quality in Journalism (QuaJou).

Table 1: Associations selected for analysis (in order of founding date).

\begin{tabular}{|r|c|l|l|}
\hline Name & Founded & Association for... & Website \\
\hline Arbus & 1930 & critical media usage and media reform & www.arbus.ch \\
\hline QuaJou & 1999 & the promotion of quality in journalism & www.quajou.ch \\
\hline Media Women & 2014 & equal representation of women in media & www.medienfrauen.ch \\
\hline Media for All & 2015 & public service, plurality, and democracy & mfa-mpt.ch \\
\hline Media Diversity & 2017 & media plurality and factual reporting & medienvielfaltschweiz.ch \\
\hline Strong Media & 2017 & the future of media and journalism & www.mediaforti.ch \\
\hline VMZ & 2017 & diversity and competition in journalism & www.medienmitzukunft.org \\
\hline
\end{tabular}

Data were gathered in an iterative process combining document analysis (see Bowen 2009; Karppinen and Moe 2012) and expert interviews (see van Selm and Hellberger 2019; van Audenhove and Donders 2019). The author first collected and read all documents accessible online about the seven associations. Based on these first insights and the literature review, she created and filled in a draft category system containing the seven categories 'general description', 'members', 'topics and agenda', 'activities', 'resources', 'No Billag and other events' and 'networks'. The author then conducted an interview with a leading activist of each association, asking for clarification and for gathering more information.7 Finally, a thematic analysis (see Braun and Clarke 2012), Herzog, Handke and Hitters 2019) of documents, notes from the interviews and the filled in category system produced three main themes. These are discussed in the next section.

\section{Main findings of the thematic analysis}

The findings of the investigation on media policy activism in Switzerland are structured along three main themes: the first theme - 'It was not so much No Billag, but' - summarizes the aims and motivations of these associations, including the advocacy for PSM and the event that triggered their formation. The second theme - 'Ideally, we would do much more' - comprises of the strategies of media policy activism and discusses the lack of resources that sets their constraints. The third theme - 'It is a small biotope' - covers their relationships with both allies and adversaries. Aside from media industry players, political parties and state actors, this includes other associations and the civil society.

\section{Aims and motivations, or: 'It wasn't No Billag, but...'}

Some of the associations studied here emerged right before the No Billag vote on 4 March 2018. The national referendum on the question of abolishing the license fees for PSM and private regional broadcasters - Billag was the name of the collection company at the time - was rejected by 71.6 per cent of the voters at the polls (see SRF 2018). Despite its clear rejection, No Billag has been undoubtedly the most important referendum on media policy in Switzerland so far. Also, unlike many other national referenda, it stirred a fierce public debate (fög 2018): about PSM, its role and remit and 
about the public interest in the media industry. One could therefore reasonably assume that the prospect of No Billag was a main reason for the formation of some of the associations and the rise in media policy activism in Switzerland in general.

The analysis shows, however, that the formation of the associations studied here was not triggered by No Billag. Media for All and Media Women say that they already existed when the libertarians behind this popular initiative announced that they start collecting signatures. 8 Strong Media says that their foundational meeting in October 2017 had nothing to do with the beginning of the campaigning phase of No Billag - the timing was a coincidence. VMZ says that it wanted to strengthen the position of small media owners in the press and online sector. Media Diversity, finally, says that their main concern was not No Billag, but the purchase of local newspapers in the Winterthur area by Christoph Blocher. Eighty-year-old billionaire Blocher, who still plays an important role in the conservative Swiss People's Party (SVP), owns various media in Switzerland (see SDA 2018).

All associations share the aim of safeguarding diversity in the media. When asked specifically about the role of the SRG, interview partners agree on its value for the Swiss media system. However, only two associations - Media for All and Strong Media - mention the importance of PSM in their statutes. Instead, the associations' statutes include broader descriptions such as the Swiss media landscape, journalism as a profession, or journalistic or cultural content. Strong Media and the VMZ envision a technologically neutral scheme for media subsidies and an open infrastructure for journalistic content. Arbus and QuaJou advocate for quality in old and new media. The Media Women want to strengthen the role of women in the entire industry. Nevertheless, while Media Diversity and VMZ have a strong connection with print media, Arbus and Media for All are closer to PSM.

The different aims and motivations of the associations affected their reaction to No Billag. Six of the seven associations decided not to get involved in the campaign. Of those six, only Arbus and Strong Media issued a statement calling for the referendum's rejection. In contrast, Media for All decided to engage in campaigning. For the numerous filmmakers among their members, the stakes were high as the SRG is the most important buyer of Swiss film productions. During the campaign, Media for All produced a series of video clips9 on the negative consequences of No Billag, visited schools and was present at the Locarno Film Festival in August 2017. Media for All, along with the non-partisan political committee 'No to the end of Broadcasting' and the young liberals of 'Operation Libero', became a main voice of the opposition to No Billag.

\section{Strategies and constraints, or: 'Ideally, we would do much more'}

The analysis shows that the seven associations selected for this study differ quite strongly regarding their activities (see Table 2). The differences concern their political style (some have an 'inside strategy', others an 'outside strategy' and others describe themselves as politically neutral or nonpartisan), the means of mediated communication they employ and the strategies they use to explain, discuss and promote their cause among their members. However, when asked about these activities, all presidents and board-members sooner or later said what sounds familiar to anyone doing voluntary work: '[i]deally, if our resources were not that scarce, we would do much more'. Due to financial and time constraints, associations are forced to limit themselves to activities that seem most effective and important in advancing their cause.

Four of the seven associations use elements of an 'inside strategy' of political participation: Arbus, Media for All, Strong Media and VMZ submitted statements in public consultations or accepted invitations to political hearings. Arbus regularly submits complaints to the Press Council. Two associations use elements of an 'outside strategy': Media Diversity has tossed leaflets targeting the 
local newspaper into mailboxes of every household in the city of Winterthur. Media for All has organized rallies during their campaign against No Billag. Media Women and QuaJou, in contrast, describe themselves as politically neutral or non-partisan. Consequently, both abstain from making any political statements. The Media Women, e.g., did not participate in organizing the national Women Strike of 14 June 2019 (see Foulkes 2019) and did not openly call for their members to take part.

Table 2: Activities of associations dedicated to media policy activism in Switzerland.

\begin{tabular}{|c|c|c|c|c|c|c|c|c|c|c|}
\hline & 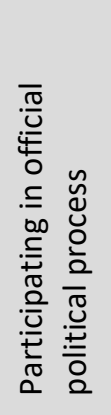 & 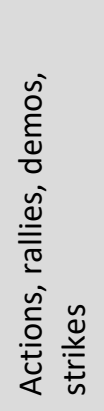 & 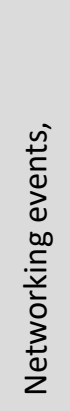 & 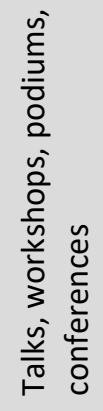 & 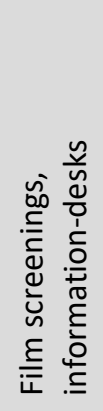 & 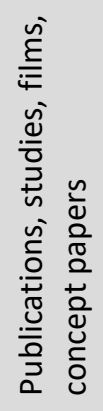 & 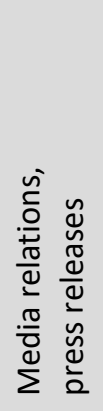 & $\begin{array}{l}\stackrel{0}{0} \\
\text { a } \\
3 \\
3\end{array}$ & 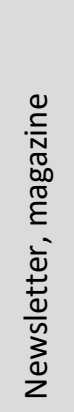 & 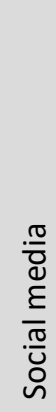 \\
\hline Arbus & $x$ & - & - & $X$ & - & - & - & $X$ & $X$ & $x$ \\
\hline Media Diversity & - & $\mathrm{X}$ & - & $(\mathrm{X})$ & - & $x$ & $\mathrm{X}$ & $x$ & - & - \\
\hline Media for All & $x$ & $\mathrm{X}$ & - & - & $x$ & $x$ & $(X)$ & $x$ & - & $x$ \\
\hline Media Women & - & $(\mathrm{X})$ & $x$ & $x$ & - & - & - & $x$ & - & $x$ \\
\hline QuaJou & - & - & $(\mathrm{X})$ & $x$ & - & - & - & $x$ & - & $x$ \\
\hline Strong Media & $x$ & - & - & $(\mathrm{X})$ & - & $x$ & $x$ & $x$ & - & $x$ \\
\hline VMZ & $x$ & - & - & - & $x$ & $(X)$ & $x$ & $x$ & $(\mathrm{X})$ & $x$ \\
\hline
\end{tabular}

Note: ' $X$ ' refers to activity that is part of the associations' strategy; ' - ' stands for activity that is not part of the associations' strategy. ' $(X)^{\prime}$ ' denotes activity that is not an essential part of the associations' strategy.

While all associations - except for Media Diversity - use social media (mainly Facebook and Twitter) besides their own website, they differ in terms of their other means of mediated communication. Four of the seven associations have sent out press releases: during the No Billag campaign, when participating in the political process or - in the case of Media Diversity - to spread the findings of a study, the association has conducted on the quality of local news reporting. Arbus, the oldest association, still uses two classical means of communication: it publishes a printed membership magazine Wellenbrecher (the 'wave breaker') twice a year with articles on current developments in the media market. Furthermore, it regularly sends out a newsletter to its members and other subscribers. According to President Daniel Römer, the newsletter has approximately 2000 subscribers (Römer 2019).

Finally, the associations use different strategies to explain, discuss and promote their cause among their members. A popular strategy is to organize or participate in panels or workshops. QuaJou organizes both an annual 'Journalism Day' and a podium every year; the Media Women organize the 'Media Women's Day' and regular meets; Arbus organizes a podium. The Media Women also offer networking activities: via their Facebook group with 900 followers and via their database with more than two hundred entries, they connect their members with jobs and offer discussion spaces. Media Diversity and Strong Media make use of the media scholars among their board members: either by conducting a study on the quality of local news reporting or by writing concept papers. Media for All produced video clips and organized film screenings; VMZ had an information desk at the 1 May festival in Zurich. 
Due to a lack of financial resources and active members, the seven associations have abstained from (or discontinued) certain activities. Arbus, for example, has dismantled its once broad network of local branches and regularly discusses its potential dissolution at annual meetings. Overall, the associations consist of ten to twenty active members and their annual membership fees lie between 20 and $50 \mathrm{CHF}$. Only the small media organizations that are members of VMZ pay a fee of 500 CHF. Media Diversity, Media for All and Strong Media received donations during recent actions; Strong Media also collected a considerable number of supporters with their two public foundation events. However, similarly to the other associations, Strong Media cannot afford an administration office. That is why the association has only handpicked members, says President Manuel Puppis (2019).

\section{Allies and adversaries, or: 'It is a small biotope'}

Apart from the Media Women, whose main adversary is patriarchy, all associations studied here have a shared nemesis: highly concentrated private media that, supported by neo-liberal politicians with a desire to deregulate, can dominate the media market. The leading activists interviewed for this study mentioned two (other) associations symbolic for this shared nemesis. The Swiss Media Association, on the one hand, which is the former Publishers Association, represents the interests of private media owners. Action for Media Freedom, on the other hand, is a forum for right-wing parliamentarians of the Swiss People's Party (SVP) and the Liberal-Democratic Party (FDP). Both associations are vocal opponents of PSM and of any proposal to promote media pluralism by regulating media concentration or by granting direct subsidies beyond the broadcasting sector.

Arbus describes itself as the 'clear opposite' to Action for Media Freedom. Similar to Media Diversity, Arbus' members generally support the Social Democratic Party; among them are several parliamentarians. The VMZ, on the other hand, sees itself as an 'Alternative Publishers' Association'. Since the Swiss Media Association usually bases its decisions on the interests of large media organizations, small and alternative media have decided to split off and form the VMZ. This is working well so far, says Co-President Camille Roseau (2019): shortly after its formation, the VMZ was already invited to a political round table by the media minister. Swiss ministers and regulatory bodies generally acknowledge the concerns of advocacy groups and value their expertise. Accordingly, associations dedicated to media policy activism perceive the media minister and the regulator as allies rather than as adversaries.10

The associations studied here see each other as allies. On some occasions, they work together - for example, when drafting public consultation submissions. Membership in more than one association is common practice, as is collective membership of one association in another. Some associations meet regularly with unions; many activists are union members. The media reform movement is a small biotope, activists say; they all know each other well. For a short time during the No Billag campaign it looked as if Media for All could become an umbrella organization for all associations dedicated to media policy activism. Activists know that such pooling of resources would make sense. However, aside from their different aims and motivations, tensions between some of the leading activists are preventing this.

Despite being the main beneficiary of their advocacy, ordinary citizens are rather unreliable allies for the associations. All of them agree that the average citizen does not know much about the media system and is not particularly interested in media policy issues. All associations see the clear rejection of No Billag as an encouragement for their work and most of them are generally open for anyone to join. However, none of them currently plans on recruiting more members, particularly beyond the media industry. Even if public debates about the media attract laypeople, media policy activism brings 
together media professionals, they say. Laypeople, Philipp Cueni (2019) posits, are better served by the membership associations of the SRG, who offer seminars on the basics of media policy to their members.

\section{Conclusions and outlook}

The goal of this study was to analyse the rise of media policy activism in Switzerland and the role that the Swiss Broadcasting Corporation (SRG) plays in the agenda of seven associations dedicated to this kind of advocacy. The analysis of these associations - a common form of organization for civic advocacy in Switzerland - used a case study approach to combine document analysis and expert interviews with leading activists. It produced three main themes: '[i]t was not so much No Billag, but [...]' revealed the main goals and motivations of these associations, including the advocacy for PSM and the event that triggered their foundation. 'Ideally, we would do much more' covered the strategies of media policy activism and showed how the lack of resources sets tight constraints. 'It is a small biotope' summarized findings about the associations' relationships with both allies and adversaries.

Most of the activists responded quickly to the interview request and provided information eagerly. Many already knew the author or identified her as an ally because of her previous research. A main difficulty was the sampling of associations. One could argue that participative media projects or unions should have been included as well or that organizations such as Media Women or QuaJou who identify as politically neutral or non-partisan should not have been included, despite the political significance of their cause. Difficulties with drawing clear boundaries are a common problem both in case study (see Broughton Micova 2019: 73) and in social movement research (see Johnston 2014: 8). A next study could develop a questionnaire with closed answer categories and administer it to a larger number of associations.

The study confirms some of the findings of previous research on media policy activism. As expected, resources of the seven associations are scarce, which is why they must set clear priorities in their activities. The media reform movement in Switzerland is also by no means free of tensions, which prevents pooling of resources to fight 'big business', the shared nemesis. In line with previous research, only two of the seven associations studied here have employed an 'outside strategy' at some point, and four applied an 'inside strategy' that is much more common in this field. Unfortunately, though, this also means that media policy activism does not reach the level of public visibility of social movements protesting for other causes, like for example the environmentalist movement.

All associations studied here embrace - to a differing degree - digital technologies as means of communication. Digitization itself is perceived as a contextual factor affecting the funding of journalism. According to Strong Media and the VMZ, the media industry needs to tackle the shift of advertising money from journalism to digital platforms and face the challenge of distributing journalism through new channels. More specific digital topics like data protection or copyright, however, are left to other associations like the 'Digital Society' (see Digitale Gesellschaft n.d.). Including some elements of digital activism into media policy activism could, however, attract younger people. 'Digital Natives' oftentimes feel more familiar with internet applications than with journalism and media organizations.

The assumption that No Billag was the 'policy window' responsible for the rise of media policy activism in Switzerland was not supported, though. Despite the temporal overlap, associations say that they had other motives for their formation. They mentioned concentration processes and financing difficulties in the press sector as their main concern. Fighting for strong PSM does, in general, not play a main role in their agenda. Consequently, it is not surprising that only one association (Media for All) 
became part of the opposition to No Billag during the political campaign. One could, however, argue that small and alternative media organizations in the print and online sector indeed need support of these associations much more urgently than the SRG, who is the largest media organization in the Swiss media market.

The associations have political impact, but they are not visible to the public in general. The lack of resources prevents the associations from including laypeople; they will therefore remain gatherings of media professionals or 'well-informed groups' (Horz 20168: 239). All activists interviewed here advise laypeople to become members of the SRG membership associations, if they wish to learn about, engage with or support PSM. These membership associations are in theory the main platform for civic advocacy for PSM in Switzerland, but they are 'toothless' when it comes to media policy activism (see, for example, Baldi 20078; Puppis and Künzler 2011; Tuchschmid 2015). If the SRG management wants to see civic advocacy for PSM, their membership associations provide a valuable platform. But to encourage media policy activism, a reform is needed.

Media policy activism in Switzerland could soon benefit from a broader societal trend. Due to the global 'fake news' debate and the challenges of digitalization, the Swiss cantons have decided to invest in citizens' level of media literacy. Media studies and computer science recently became a compulsory subject in elementary school of German-speaking cantons (D-EDK 20185 ). Even if there are still some questions to be answered regarding the implementation of these subjects and the training of the teachers (see Olff 2018), children and young adults and with them society at large will soon become much more media (policy) literate, which is a prerequisite for media policy activism.

\section{References}

Aslama Horowitz, Minna and Nieminen, Hannu (2017), 'Diversity and rights. Connecting media reform and public service media', La Revista Científica de Información y Comunicación, 14, pp. 99-119 .

Baldi, Paolo (2007), 'Media accountability in Europe: A fragmented picture', in P. Baldi (ed.), Broadcasters and Citizens in Europe. Trends in Media Accountability and Viewer Participation, Bristol: Intellect, pp. 17-32.

Boateng, Boatema (2011), 'Whose democracy? Rights-based discourse and global intellectual property rights activism', in R. Mansell and M. Raboy (eds), The Handbook of Global Media and Communication Policy, Malden, MA: Wiley-Blackwell, pp. 261-75.

Bonfadelli, Heinz (2019), face-to-face interview with C. Schweizer, 5 September.

Borgman-Arboleda, Catherine (2011), 'Engendering scholar-activist collaborations. An evaluator's perspective', in P. M. Napoli and M. Aslama (eds), Communications Research in Action. ScholarActivist Collaborations for a Democratic Public Sphere, New York: Fordham University Press, pp. 313-32.

Bowen, Glenn A. (2009), 'Document analysis as a qualitative research method', Qualitative Research Journal, 9:2, pp. 27-40.

Braun, Virginia and Clarke, Victoria (2012), 'Thematic analysis', in H. Cooper, P. M. Camic, D. Long, A. T. Panter, D. Rindskopf and K. J. Sher (eds), APA Handbook of Research Methods in Psychology, Washington, DC: American Psychological Association, pp. 57-71.

Brougton Micova, Sally (2019), 'Case study research', in H. van den Bulck, M. Puppis, K. Donders and L. van Audenhove (eds), The Palgrave Handbook of Methods for Media Policy Research, Cham: Palgrave Macmillan, pp. 71-84. 
ch.ch (n.d.a), 'What is a federal popular initiative? A federal popular initiative is a way for citizens to amend the federal constitution', https://www.ch.ch/en/demokratie/political-rights/popularinitiative/what-is-a-federal-popular-initiative/. Accessed 2 April 2020 .

- - (n.d.b), 'Mandatory referendums and optional referendums in Switzerland. When are people called to vote on laws, and when not?', https://www.ch.ch/en/demokratie/political-

rights/referendum/mandatory-referendums-and-optional-referendums-in-switzerlan/. Accessed 2 April 2020.

Collins, Steve (2018), 'Acting out. Resisting copyright monopolies', in G. Meikle (ed.), The Routledge Companion to Media and Activism, London: Routledge, pp. 346-54.

Cueni, Philipp (2019), telephone interview with C. Schweizer, 6 September.

D-EDK (2015), Schlussbericht der Arbeitsgruppe zu Medien und Informatik im Lehrplan 21, https://www.regionalkonferenzen.ch/sites/default/files/2019-02/Schlussbericht_MI_2015-0223_mit_Anhang.pdf. Accessed 2 April 2020.

Dencik, Lina and Wilkin, Peter (2018), 'Digital activism and the future of worker resistance', in G. Meikle (ed.), The Routledge Companion to Media and Activism, London: Routledge, pp. 125-33.

Digitale Gesellschaft (n.d.), 'Über uns', https://www.digitale-gesellschaft.ch/uber-uns/. Accessed 2 April 2020.

Dunham, lan (2016), 'Fight for the future and net neutrality: A case study in the origins, evolution, and activities of a digital-age media advocacy organization', International Journal of Communication, 10, pp. 5826-39 .

Ellis, Katie and Goggin, Gerard (2018), 'Disability and media activism', in G. Meikle (ed.), The Routledge Companion to Media and Activism, London: Routledge, pp. 355-64.

Feigenbaum, Anna (2018), 'Can the women's peace camp be televised? Challenging mainstream media coverage of Greenham Common', in G. Meikle (ed.), The Routledge Companion to Media and Activism, London: Routledge, pp. 47-56.

Fenton, Natalie (2018), 'Media activism. Media change?', in G. Meikle (ed.), The Routledge Companion to Media and Activism, London: Routledge, pp. 329-36.

Filmmakers (2018), 'Filmmakers against No Billag', https://www.facebook.com/filmschaffende/. Accessed 7 June 2020.

fög (2018), Abstimmungsmonitor. Vorlagen vom 4. März 2018, https://www.foeg.uzh.ch/dam/jcr:0a7ad23e-d48b-48f8-92cb2acb88a7e29d/Abstimmungsmonitor_M\%C3\%A4rz_2018.pdf. Accessed 2 April 2020.

Foulkes, Imogen (2019), 'Swiss women strike for more money, time and respect', BBC, 14 June, https://www.bbc.com/news/world-europe-48615911. Accessed 2 April 2020.

Freedman, Des (2008), The Politics of Media Policy, Cambridge: Polity Press.

- - (2019), 'Media policy activism', in H. van den Bulck, M. Puppis, K. Donders and L. van Audenhove (eds), The Palgrave Handbook of Methods for Media Policy Research, Cham: Palgrave Macmillan, pp. 627-39.

Freedman, Des and Obar, Jonathan A. (2016), 'Media reform. An overview', in D. Freedman, J. A. Obar, C. Martens and R. W. McChesney (eds), Strategies for Media Reform: International Perspectives, New York: Fordham University Press, pp. 3-18.

Gallagher, Margaret (2011), 'Gender and communication policy: Struggling for space', in R. Mansell and M. Raboy (eds), The Handbook of Global Media and Communication Policy, Malden, MA: Wiley-Blackwell, pp. 449-66.

Galliker, Hans-Rudolf (2018), "Vereinsmeier". Uster und seine Vereine von 1800 bis in die Gegenwart, https://www.uster.ch/_docn/1894085/Publ_Vereinsmeier-2018-low_20181030.pdf. Accessed 2 April 2020. 
Geiser, Urs (2018), 'Vote March 4, 2018. Attack on public broadcasting licence fee clearly fails', SWI, 4 March, https://www.swissinfo.ch/eng/vote-march-4--2018_attack-on-public-broadcast-licencefee-set-to-fail/43935166. Accessed 2 April 2020 .

George, Alexander L. and Bennet, Andrew (2005), Case Studies and Theory Development in the Social Sciences, Cambridge, MA: MIT.

Hasse, Kerstin (2019), telephone interview with C. Schweizer, 2 October.

Helmig, Bernd, Gmür, Markus, Bärlocher, Christoph, von Schnurbein, Georg, Degen, Bernard, Nollert, Michael, Budowski, Monica, Sokolowski, Wojciech and Salomon, Lester M. (2011), The Swiss Civil Society Sector in a Comparative Perspective, VMI research series - vol. 6, Fribourg: VMI.

Herzog, Christian, Handke, Christian and Hitters, Erik (2019), 'Analyszing Talk and Text III: Thematic Analysis', in H. van den Bulck, M. Puppis, K. Donders and L. van Audenhove (eds), The Palgrave Handbook of Methods for Media Policy Research, Cham: Palgrave Macmillan, pp. 385-401.

Hintz, Arne (2018), 'Policy activism. Advocating, protesting and hacking media regulation', in G. Meikle (ed.), The Routledge Companion to Media and Activism, London: Routledge, pp. 319-28.

Horz, Christine (2018), 'Networking citizens. Public service media and audience activism in Europe', in G. Lowe, H. van den Bulck and K. Donders (eds), Public Service Media in the Networked Society, Goteborg: Nordicom, pp. 227-44.

Johnston, Hank (2014), What Is a Social Movement?, Cambridge: Polity Press.

Jost, Hans Ulrich (1992), 'Zur Geschichte des Vereinswesens in der Schweiz', in P. Hugger (ed.), Handbuch der schweizerischen Volkskultur. Leben zwischen Tradition und Moderne. Ein Panorama des Schweizerischen Alltags, vol. 1, Zurich: Offizin, pp. 467-84.

Karaganis, Joe (2011), 'Cultures of collaboration in media research', in P. M. Napoli and M. Aslama (eds), Communications Research in Action. Scholar-Activist Collaborations for a Democratic Public Sphere, New York: Fordham University Press, pp. 287-312.

Karppinen, Kari and Moe, Hallvard (2012), 'What we talk about when we talk about document analysis', in N. Just and M. Puppis (eds), Trends in Communication Policy Research. New Theories, Methods and Subjects, Bristol: Intellect, pp. 177-93.

Kavada, Anastasia (2018), 'Connective or collective? The intersection between online crowds and social movements in contemporary activism', in G. Meikle (ed.), The Routledge Companion to Media and Activism, London: Routledge, pp. 108-16.

Kingdon, John W. (1984), Agendas, Alternatives, and Public Policy, Boston, MA: Little Brown.

Lentz, Becky (2011), 'Media infrastructure policy and media activism', in J. Downing (ed.), Encyclopedia of Social Movement Media, Thousand Oaks, CA: Sage, pp. 323-26.

- - (2016), 'Media policy literacy. A foundation for media reform', in D. Freedman, J. A. Obar, C. Martens and R. W. McChesney (eds), Strategies for Media Reform: International Perspectives, New York: Fordham University Press, pp. 19-35.

Löblich, Maria (2016), 'Dissent and political participation: The many faces of communication policy advocacy and activism', Communication, Culture \& Critique, 9:3, pp. 395-416.

Milan, Stefania (2013), Social Movements and Their Technologies: Wiring Social Change, Basingstoke: Palgrave Macmillan.

Milan, Stefania and Hintz, Arne (2011), 'Media activists and communication policy processes', in J. Downing (ed.), Encyclopedia of Social Movement Media, Thousand Oaks, CA: Sage, pp. 317-19.

Moran, Rachel E. and Bui, Matthew N. (2019), 'Race, ethnicity, and telecommunications policy issues of access and representation: Centering communities of color and their concerns', Telecommunications Policy, 43:5, pp. 461-73.

Napoli, Philip M. (2007), 'Public interest media activism and advocacy as a social movement: A review of the literature', McGannon Center working paper series 21, Fordham University, https://fordham.bepress.com/mcgannon_working_papers/21/. Accessed 2 April 2020 . 
Okon, Patrick Edem (2017), 'Rethinking media policy in anglophone Sub-Saharan Africa: The challenge of community media', Media Watch, 8:2, pp. 270-86.

Olff, Sabine (2018), 'Neues Primar-Schulfach. Für das neue Schulfach Informatik müssen auch die Lehrer büffeln', SRF, 16 August, https://www.srf.ch/kultur/gesellschaft-religion/neues-primarschulfach-fuer-das-neue-schulfach-informatik-muessen-auch-die-lehrer-bueffeln. Accessed 2 April 2020 .

Puppis, Manuel (2019), telephone interview with C. Schweizer, 13 September.

Puppis, Manuel and Künzler, Matthias (2011), 'Coping with change: The reorganization of the Swiss public service broadcaster SRG SSR', Studies in Communication Sciences, 11:2, pp. 167-90.

- - (2016), 'Reforming or conforming? The contribution of communication studies to media policy in Switzerland', in D. Freedman, J. A. Obar, C. Martens and R. W. McChesney (eds), Strategies for Media Reform: International Perspectives, New York: Fordham University Press, pp. 239-51.

Regan Shade, Leslie (2011), 'Media reform in the United States and Canada: Activism and advocacy for media policies in the public interest', in R. Mansell and M. Raboy (eds), The Handbook of Global Media and Communication Policy, Malden, MA: Blackwell, pp. 147-65.

Rennie, Ellie (2011), 'Community media and the third sector', in J. Downing (ed.), Encyclopedia of Social Movement Media, Thousand Oaks, CA: Sage, pp. 115-21.

Römer, Daniel (2019), e-mail interview with C. Schweizer, 28 September.

Roseau, Camille (2019), telephone interview with C. Schweizer, 4 September.

Scheu, Nina (2019), telephone interview with C. Schweizer, 13 September.

Schumacher , Beatrice (2017), Vereine in der Schweiz - Die Schweiz und ihre Vereine. Ein historischer Überblick, Zurich: Cornelia Hürzeler on behalf of the Migros-Kulturprozent, http://www.impulszusammenleben.ch/userfiles/file/pdf/PDFs\%20Freiwilligenarbeit/Fachartikel\%20Vereine\%20in\%2 Oder\%20Schweiz\%20ein\%20historischer\%20\%C3\%9Cberblick.pdf. Accessed 2 April 2020.

Schweizer Radio DRS (2008), Die Geschichte des Radios in der Schweiz von 1911-2008, https://www.srf.ch/unternehmen/content/download/3456150/file/Geschichte\%20des\%20Radios \%201911-2008.pdf. Accessed 2 April 2020.

SDA (2018), 'Controversial deal. Switzerland's largest media group strengthens dominant position', SWI, 18 April, https://www.swissinfo.ch/eng/controversial-deal-_switzerland-s-largest-mediagroup-strengthens-dominant-position/44057504. Accessed 2 April 2020.

Skinner, David, Hackett, Robert and Poynth, Stuart (2015), 'Media activism and the academy, three cases: Media democracy day, open media, and newswatch Canada', Studies in Social Justice, 9:1, pp. 86-101.

Soledad Segura, María and Waisbord, Silvio (2016): Media Movements: Civil Society and Media Policy Reform in Latin America, London: Zed Books.

SRF (2018), " "No Billag"-initiative. 71.6 Prozent sagen Nein zur Vorlage', https://www.srf.ch/news/schweiz/abstimmungen/abstimmungen/no-billag-initiative/no-billaginitiative-71-6-prozent-sagen-nein-zur-vorlage. Accessed 2 April 2020.

SRG SSR (n.d.), 'SRG: Organizationally something special', https://metro.srgssr.ch/en/organization/overview. Accessed 2 April 2020.

SRG Statutes 2009 (2016), 29 April, https://www.srgssr.ch/fileadmin/dam/documents/Organisation/Statuten_SRG_en.pdf. Accessed 2 April 2020 .

Swiss Civil Code 1912 (2020), 1 January, https://www.admin.ch/opc/en/classifiedcompilation/19070042/index.html. Accessed 2 April 2020. 
Tuchschmid, Benno (2015), 'SRG-Trägerverein: Eine «Alibiübung» oder doch «gelebte Demokratie»?', Aargauer Zeitung, 2 May, https://www.aargauerzeitung.ch/schweiz/srg-traegerverein-einealibiuebung-oder-doch-gelebte-demokratie-129097571. Accessed 2 April 2020.

Ugland, Erik (2019), 'Expanding media law and policy education: Confronting power, defining freedom, awakening participation', Communication Law and Policy, 24:2, pp. 271-306.

van Audenhove, Leo and Donders, Karen (2019), 'Talking to people III: Expert interviews and elite interviews', in H. van den Bulck, M. Puppis, K. Donders and L. van Audenhove (eds), The Palgrave Handbook of Methods for Media Policy Research, Cham: Palgrave Macmillan, pp. 179-97.

van Selm, Martine and Hellberger, Natali (2019), 'Talking to people II: Qualitative interviews', in H. van den Bulck, M. Puppis, K. Donders and L. van Audenhove (eds), The Palgrave Handbook of Methods for Media Policy Research, Cham: Palgrave Macmillan, pp. 161-77.

Yin, Robert K. (2009), Case Study Research: Design and Method, 4th ed., Los Angeles, CA: Sage.

\section{Notes}

1. According to public data of the Federal Chancellery, the Swiss tradition of holding national referenda started with the revision of the Federal Constitution (1848). In the last 50 years, there were on average eight national referenda per year. National referenda on media policy issues are very rare. Before No Billag (2018) and the referendum on the household levy (2015), the Swiss voted on fixed book prices (2012), subsidies for the cultural sector (1994) and on articles in the Federal Constitution for radio and TV $(1984,1976,1957)$ and film (1958).

2. Culture and politics are closely linked and it is up to the researcher to decide whether they want to focus on political or cultural elements of a social movement. What is clear, though, is that for some movements, cultural processes are more important than for others (Johnston 2014: 72, 93).

3. The Collaborative Grants programme (2006-08) was part of the Necessary Knowledge for a Democratic Public Sphere project that was funded by the US Social Science Research Council. It funded forty-four research partnerships (Borgman-Arboleda 2011; Karaganis 2011).

4. Founding an association is legally completed as soon as the purpose of the association, the financial means and the organizational structure are written down in the statutes (Art. 60 Swiss Civil Code 1912).

5. Schumacher explains this paradoxical situation with a 'total neoliberal reconstruction' (2017: 45). In a highly differentiated western society, associations are seen as an ideal for emotional connection and reciprocity and a way to restore trust and solidarity (Schumacher 2017: 46).

6. At that time, the SRG was still called Swiss Radio Corporation (Schweizer Radio DRS 2008: 13).

7. The interviewees were Heinz Bonfadelli (Executive Board Member of Media Diversity), Philipp Cueni (former President of QuaJou, former board-member of Media for All), Kerstin Hasse (President of Media Women), Manuel Puppis (President of Strong Media), Daniel Römer (President of Arbus), Camille Roseau (Co-President of Media with a Future) and, Nina Scheu (former Executive Board Member of Media for All). Most interviews were conducted over the phone, one face-to-face and, one over e-mail between 4 September and 2 October 2019.

8. Swiss citizens can launch a popular initiative by collecting 100,000 signatures. They can also trigger an 'optional' referendum against a political decision by collecting 50,000 signatures. The government itself has to hold 'mandatory' referenda, e.g. in case of a change in the Federal Constitution (see ch.ch n.d.a, n.d.b). 
9. Filmmakers 'Filmmakers against No Billag' (2018 ), e.g., created three short videos depicting everyday life after privatization of sidewalks, elementary school and the fire brigade: https://www.facebook.com/filmschaffende/.

10. The Federal Office of Communication (BAKOM) regulates the broadcasting sector, it is part of the Federal Department of Environment, Transport, Energy and Communication (UVEK).

\section{Acknowledgements}

The author thanks all her interview partners, the reviewers, the editors of the special issue, Prof. Dr. Natascha Just and Johanna Burger, for their time and support. The author received no specific funding for this work and does not have any conflicts of interest.

\section{Copyright}

Corinne Schweizer has asserted their right under the Copyright, Designs and Patents Act, 1988, to be identified as the author of this work in the format that was submitted to Intellect Ltd.

This article was accepted for publication in Interactions (Journal) Studies in Communication \& Culture 11/2 in Summer 2020. See: https://www.intellectbooks.com/interactions-studies-in-communicationculture 